\title{
РОЗДІЛ I
}

\section{ТЕОРІЯ ТА ІСТОРІЯ ДЕРЖАВИ І ПРАВА. КОНСТИТУЦИИНЕ ТА МІЖНАРОДНЕ ПРАВО}

УДК: 342.51

DOI: https://doi.org/10.32366/2523-4269-2020-73-4-11-19

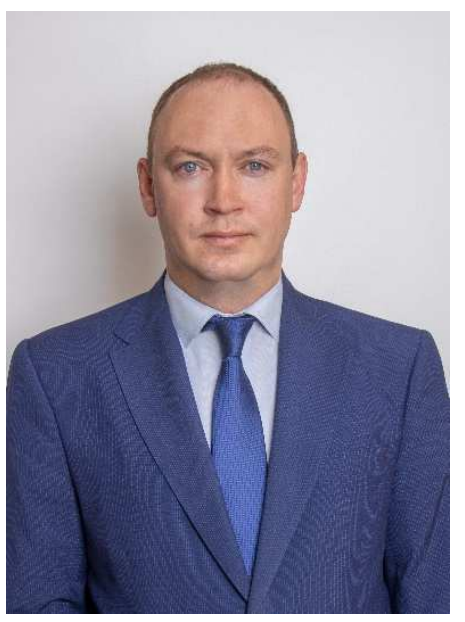

Спринцев Пилип Сергійович, кандидат юридичних наук

(Донецький юридичний інститут МВС Украӥни, м. Кривий Piг)

ORCID: https://orcid.org/0000-0002-9790-9565

Носевич Надія Русланівна, (Донечький юридичний інститут МВС України, м. Кривий Piг) ORCID: https://orcid.org/0000-0002-1112-9788

\section{ЦЕНТРАЛЬНЕ БЮРО РОЗСЛІДУВАНЬ ІНДІЇ: ІСТОРІЯ, ПРАВОВА ОСНОВА ПРОФЕСІЙНОЇ ДІЯЛЬНОСТІ, ЗАВДАННЯ, СТРУКТУРА}

У межах науково-правничої статті розглянуто історію, правову основу пробесійної діялъності, структуру та завдання Центрального бюро розслідуванъ Індіі. Аналізуючи вказані предметні аспекти, автори звернулися до чинного законодавства Індії про пробесійну діяльність Централъного бюро розслідуванъ, оббіиійного інтернет-сайту Централъного бюро розслідуванъ, а також до наукових пращъ окремих вітчизняних та зарубіжних фбахівиів із иієї проблематики.

Ключові слова: Централъне бюро розслідуванъ; розслідування; структура ЦБР; підрозділ ЦБР; службовечъ ЦБР.

Постановка проблеми. Сучасні системи правоохоронних органів окремих держав складаються з багатьох елементів, більш або менш відмінних один від одного за своїм функціонально-цільовим призначенням. У межах даного змістовно-смислового контексту під такими елементами ми розуміємо ті чи інші державні відомства, міністерства, департаменти, служби, бюро, агентства, які входять до так званого «силового блоку». Правоохоронна складова цього блоку передбачає дії із забезпечення прав і свобод громадян та захисту національних інтересів держави. Це здійснюється для боротьби 3 організованою злочинністю, зокрема 3 міжнародним тероризмом, розслідування певних протиправних діянь, відтворення ефективної системи національної безпеки та оборони.

Яскравим прикладом у межах указаного проблематичного контексту $\epsilon$, безумовно, Федеральне бюро розслідувань США (далі - ФБР), яке, поряд із поліцейськими органами штатів: Управлінням боротьби з наркотиками, Центральним розвідувальним управлінням (далі - ЦРУ), Міністерством внутрішньої безпеки, Секретною службою - водночас i 
розслідує тяжкі кримінальні злочини, і веде боротьбу з міжнародним тероризмом, і здійснює розвідувальну й контррозвідувальну діяльність.

Однак не менш важливим та більш предметним науково-правничим $є$ питання про наявність чи, навпаки, відсутність функціонально-цільових аналогів ФБР у сучасних національних правоохоронних системах інших держав світу.

Аналіз останніх досліджень і публікацій. Проаналізувавши останні дослідження та публікації, нами було 3'ясовано, що $є$ велика кількість праць щодо історії розвитку правоохоронних органів країн світу. Зокрема, розробкою даного питання займалися такі українські та зарубіжні науковці, як Т. В. Апарова, В. О. Боняк, А. Б. Венгеров, Н. С. Виноградов, Л. В. Головко, К. Ф. Гуценко, Д. І. Дорошенко, П. П. Спіфанов, Н. М. Калинюк, В. В. Лазарева, М. М. Марченко, А. К. Романов, М. М. Тихомиров, Б. Л. Філімонов та інші.

Метою статті $\epsilon$ дослідження історичних умов формування та правової основи професійної діяльності Центрального бюро розслідувань Індії, вивчення його структури й завдань, а також з'ясування недоліків законодавства щодо повноважень Центрального бюро розслідувань Республіки Індія та визначення на основі компаративного аналізу 3 американським ФБР пріоритетів у подальшій його діяльності.

Виклад основного матеріалу. Власне, на окрему науково-правничу увагу заслуговує проблематика «спеціальних», «вищих» цілей, завдань і функцій, притаманних окремим, достатньо могутнім правоохоронним відомствам, які засновані й діють у тій чи іншій державі.

Так, першою відмінною рисою таких відомств $є$ суто загальнонаціональний територіальний масштаб для їхніх професійних дій. По-друге, йдеться про те, що ці державні органи діють виключно на основі урядового мандату, тобто вони виконують свої професійні обов'язки від імені або за прямим дорученням голови держави або ж центрального уряду, окремого міністра. Тобто вони не перебувають у жодному підпорядкуванні місцевим / регіональним державним керівникам, у тому числі й найвищим, які представляють інший галузевий орган виконавчої влади. Таким чином, правовою основою для їхніх професійних дій $є$ лише загальнодержавне, а не місцеве / регіональне законодавство. Третьою ж відмінною рисою таких відомств є певна, а іноді й цілковита спорідненість їхніх окремих професійних завдань із відповідними завданнями інших відомств «силового блоку».

Така спорідненість може проявлятися в тому, що зазначені правоохоронні органи здійснюють відповідні функції, як вважається, на більш високому професійному рівні, вирішуючи набагато складніші галузеві завдання. Наприклад, мова може йти про їхню здатність розслідувати надзвичайно заплутані, найбільш складні кримінальні злочини загальнонаціонального масштабу, які не змогла розслідити місцева поліція.

Більш ніж столітня світова практика свідчить про те, що відповідні аналоги ФБР у світі все ж таки існують, але їх надзвичайно мало. Більшість урядових відомств окремих держав світу, які, на нашу думку, помилково асоціюються із ФБР, - британське МІ 5 [12], канадське CSIS [4], австралійська ASIO [3], південноафриканське SSA [13], російське ФСБ [1] - виконують переважно розвідувальні та контррозвідувальні функції, зосередившись на проблемах загроз національній безпеці. Ці служби майже не охоплюють цілей та завдань класичного правоохоронного, кримінологічного, криміналістичного характеру.

Однак певним, але далеко не цілковитим, тобто дещо обмеженим функціональноцільовим аналогом ФБР є Центральне бюро розслідувань Республіки Індія (далі - ЦБР), до професійної компетенції якого належить попередження та розслідування найтяжчих кримінальних злочинів, наслідки вчинення яких безпосередньо зачіпають державні інтереси Індії та життєві інтереси її багатонаціонального суспільства. Але службовці індійського ЦБР, на відміну від спеціальних агентів американського ФБР, не виконують професійних 
обов'язків із розвідувальної та контррозвідувальної діяльності. Ці обов'язки здійснюють працівники окремого, профільного Розвідувального бюро Республіки Індія.

ЦБР, на відміну від ФБР, було створено дещо пізніше. Його офіційна історія починається в 1941 році, коли Індія, будучи все ще британською колонією, вже як два роки вступила у Другу світову війну на боці своєї метрополії - Великобританії.

Так, офіційний інтернет-сайт ЦБР повідомляє 3 цього приводу таке (подається в авторському перекладі 3 мови-оригіналу джерела. - Прим. авт.): «Попередником Центрального бюро розслідувань були Поліцейські сили спеціального призначення (далі ПССП), які були створені в 1941 році Урядом Індії. Функціями ПССП було визначено розслідування випадків хабарництва та корупції, які могли трапитися протягом Другої світової війни в рамках господарської діяльності Департаменту у справах військових поставок. Керівні повноваження ПССП були їм надані Військовим міністерством. Навіть після завершення війни відчувалася потреба у Центральній урядовій службі, працівники якої розслідували б випадки хабарництва та корупції. Закон «Про Поліцейські сили спеціального призначення Делі» набув чинності у 1946 році. Згідно з цим законом, керівництво за діяльністю ПССП щодо розслідування випадків хабарництва та корупції було передано Міністерству внутрішніх справ (далі - MBC), а їхні повноваження було розширено, щоб мати змогу розслідувати діяльність усіх інших департаментів Уряду Індії. Юрисдикція цих ПССП була поширена на союзні території та могла поширюватися на території штатів за згодою Уряду того чи іншого окремого штату» [5]. Відповідно до вказаного закону, ці ПССП почали називатися Поліцейські сили спеціального призначення Делі (далі - ПССПД) [14].

Що ж стосується набуття ПССПД теперішньої назви - ЦБР - то на їхньому офіційному інтернет-сайті зазначено: «ПССПД отримали свою сучасну популярну назву Центральне бюро розслідувань - згідно з Постановою Міністерства внутрішніх справ від 01.04.1963 р. Спочатку до злочинів, розслідування яких здійснювалося на основі відповідної урядової компетенції, належали лише корупційні діяння, скоєні урядовими службовцями. У свою чергу, з огляду на організацію численних відомств державного сектору, працівники цих відомств також опинилися під наглядом ЦБР. Водночас, через націоналізацію банків у 1969 році, банківський сектор та його працівники також потрапили до сфери професійної діяльності ЦБР. Починаючи 31956 року і надалі, ЦБР отримало повноваження щодо розслідування економічних злочинів, а також таких тяжких кримінальних злочинів, як вбивства, викрадення людей, терористичні акти тощо» [5]. Першим Директором ЦБР з 1963 до 1968 рр. був Шрі Дхарамнатх Прасад Кохлі [5].

Слід окремо зауважити, що професійну діяльність ЦБР і власне це федеральне правоохоронне відомство не слід плутати 3 Національним агентством розслідувань Республіки Індія (далі - НАР), яке є окремим правоохоронним підрозділом у межах МВС Індії. Однак, на відміну від ЦБР, метою професійної діяльності НАР є комплексна боротьба 3 усіма можливими загрозами національній безпеці Індії, зокрема боротьба з тероризмом [10]. Таким чином, це виключає завдання щодо розслідування цілої низки інших тяжких кримінальних злочинів, що, у свою чергу, і $є$ компетенційною прерогативою саме ЦБР.

НАР було створено у 2009 році згідно з Законом «Про Національне агентство розслідувань» від 2008 року [11]. Так, у Преамбулі до цього Закону сказано: «Цим Законом засновується агентство 3 розслідувань, що діятиме в загальнонаціональному масштабі, розслідуючи та доводячи до судового розгляду злочини, які загрожують суверенітету, безпеці та цілісності Індії, державній безпеці, дружнім відносинам з іншими державами, а також злочини, розслідування яких спрямоване на імплементацію міжнародних договорів, угод, конвенцій та резолюцій Організації Об'єднаних Націй, іiї спеціалізованих установ та інших міжнародних організацій, які опікуються питаннями, пов'язаними 3 цією проблематикою, або побічними питаннями» [11]. 
Власне, протягом 2007-2008 рр. в уряді, політикумі та керівних колах усіх індійських штатів тривала гостра дискусія щодо необхідності боротьби 3 тероризмом індійського та міжнародного походження. Суть дискусії полягала в тому, чи потрібно заснувати окрему федеральну службу з питань попередження та розслідування терористичних актів і чи не буде вона дублювати відповідних функцій ЦБР.

Так, один із фахівців 3 цього питання Є. М. Ходатенко зазначає: «За ініціативою Манмохана Сінгха (15-го прем'єр-міністра Індіi) було створено парламентську комісію, покликану знайти вихід із ситуації, яка склалася. У березні 2008 року комісія подала на розгляд до Парламенту таку пропозицію: замість створення нової федеральної служби розширити повноваження ЦБР із розслідування злочинів, віднесених до категорії федеральних. На думку комісії, ЦБР $є$ організацією, яка має достатньо оснащення для попередження та розслідування подібних злочинів. Раніше було запропоновано заснувати 3 цією метою єдину федеральну службу, однак, як уважає комісія, створення додаткового відомства може призвести до конфліктів інтересів у межах сил безпеки країни, розмиванню їхньої юрисдикції та розпиленню людських ресурсів» [2, с. 183].

Парламент Індії у 24-й Доповіді Парламентського комітету з кадрової політики висловився «або за створення всеіндійського національного агентства, або ж за реорганізацію ЦБР подібно до американського Федерального бюро розслідувань з метою ведення всіх справ, пов'язаних із тероризмом, які мають загальнонаціональне значення» [2, c. 184]. Однак, як ми бачимо, саме перший із вказаних відомчих підходів отримав остаточну перевагу.

У свою ж чергу, на сьогодні базовими завданнями ЦБР, виходячи 3 його девізу «Старанність, Неупередженість, Чесність», є: «1) боротьба 3 корупцією у державній сфері, протидія економічним та насильницьким злочинам через ретельне розслідування та доведення справи до судового розгляду; 2) розвиток ефективних систем та процедур, спрямованих на результативне розслідування та представлення кримінальної справи в судових інстанціях того чи іншого рівня; 3) допомога в боротьбі 3 кіберзлочинами та злочинами у галузі високих технологій; 4) створення здорової атмосфери в трудових відносинах, яка сприяла б злагодженій командній роботі, вільному спілкуванню та взаємній довірі; 5) підтримка підрозділів поліції та інших правоохоронних органів у межах загальнонаціонального та міжнародного співробітництва, зокрема щодо відомчих запитів та розслідування кримінальних справ; 6) провідна роль у боротьбі 3 внутрішньою та міжнародною організованою злочинністю; 7) захист прав людини, довкілля, витворів мистецтва, стародавніх пам'яток та спадщини людської цивілізації; 8) розвиток наукового потенціалу, гуманізму та духу цікавості і прагнення до реформ; 9) боротьба за досконалість та професіоналізм у всіх сферах діяльності, щоб функціонування організації відповідало найвищим вимогам старанності та досягнень» [5].

Загальними ж цілями професійної діяльності ЦБР визначено: «Захист положень Конституції Індії та законодавства країни через ретельні розслідування та успішне представлення кримінальних справ у судових інстанціях; забезпечення лідерської позиції та керівництва силами поліції; діяльність як провідної установи для забезпечення міжтериторіальної та міжнародної співпраці у сфері правоохоронної діяльності» [5].

Попри те, що з дати створення ЦБР минуло аж 74 роки, це відомство не діє відповідно до окремого нормативно-правового акту, який можна було б назвати, наприклад, Законом «Про професійну діяльність Центрального бюро розслідувань Республіки Індії». Саме тому всюди й завжди зазначається, що єдиним підзаконним актом, який регулює професійну діяльність ЦБР, є розглянутий вище Закон «Про Поліцейські Сили спеціального призначення Делі» від 1946 року [14].

Однак не слід забувати і про зміст також згаданої вище Постанови Міністерства внутрішніх справ від 01.04.1963 року [8]. Так, у Преамбулі до неї зауважено таке: «Уряд Індії 
розглянув питання про заснування Центрального бюро розслідувань, метою діяльності якого має бути розслідування злочинів, якими на сьогодні опікуються Поліцейські Сили спеціального призначення Делі, включно з особливо важливими злочинами згідно з Законом «Про оборону Індії», зокрема про приховування коштів, чорний ринок та спекуляцію у сфері життєво важливих товарів, що може мати свої наслідки та вплив у кількох штатах; збір інформації про основні типи злочинів, участь у роботі Національного центрального бюро Міжнародної організації кримінальної поліції; підтримка служб статистики, які накопичують матеріал про скоєння кримінальних злочинів та розповсюдження інформації про злочини та злочинців, дослідження особливих злочинів або злочинів, наслідки вчинення яких охоплюють всю Індію або кілька штатів, або розкриття яких має велике значення для Уряду Індіï, або злочинів, наслідки скоєння яких охоплюють всю Індію або кілька штатів, або розкриття яких має велике соціальне значення; здійснення поліцейських розслідувань та координоване застосування законодавства щодо злочину. Як перший крок у цьому напрямку Уряд Індії вирішив створити з 1 квітня 1963 року Центральне бюро розслідувань у м. Делі, до складу якого входили б такі підрозділи...» [8]. Далі решта невеликого тексту Постанови складається лише з перерахування самих підрозділів та зазначення їхніх функцій [8].

Таким чином, це стисле «окреме законодавство про професійну діяльність ЦБР» не нормативізує докладно ані мети, ані предмету, ані стратегії, ані конкретних завдань, ані засад, ані принципів професійної діяльності ЦБР. Тому ця Постанова є морально застарілою; вона не відповідає жодним вимогам сучасності щодо ефективної боротьби з внутрішньою та міжнародною організованою злочинністю, зокрема 3 міжнародним тероризмом. Це «законодавство» нормативізувало лише саму назву відомства в цілому та назви його структурно-функціональних підрозділів, назви та кількість яких сьогодні змінено.

Не набагато змістовнішим є і Закон «Про Поліцейські сили спеціального призначення Делі» від 1946 року. Так, наприклад, у п. 3 цього закону не перераховано кримінальних злочинів, які мають розслідувати ПССПД. У ньому наголошено на тому, що Центральний Уряд Індії лише може в майбутньому визначити список таких кримінальних злочинів [14]. Отже, функції, які сьогодні виконує ЦБР, конкретні кримінальні злочини, які воно розслідує та які вказані на офіційному інтернет-сайті ЦБР, зумовлені суто правоохоронною практикою, об'єктивно та суб'єктивно визначеними пріоритетами у сфері боротьби 3 індійською злочинністю.

Таким чином, нормативні положення вказаного закону, стосуючись «неіснуючих» ПССПД, розповсюджуються $з 1$ квітня 1963 року саме на ЦБР. Так, наприклад, зміст п. 4-А визначає порядок призначення Директора ЦБР: «Центральний Уряд призначає Директора за рекомендацією Комітету, який складається з: а) Прем'єр-міністра; б) Лідера опозиції, якого визнано таким на Народному зібранні, або коли такої особи немає, то Лідера найчисленнішої опозиційної партії на зібранні; в) Міністра юстиції або Голови Верховного Суду, призначеного цим міністром» [14]. Термін посадової каденції Директора, згідно 3 п. 4-В указаного закону, становить не менше двох років [14].

Ці змістовні положення про призначення Директора дещо віддзеркалюють зміст розділу 33 «Федеральне бюро розслідувань» частини 28 «Судоустрій та судовий процес» Кодексу США, який присвячено всім правовим основам професійної діяльності ФБР США [15].

Відсутність правової основи для професійної діяльності ЦБР стала предметом гласності в Індії в 2013 році, коли Вищий суд міста Гувахаті (штат Асам) 6 листопада 2013 року прийняв скандальну Постанову про те, що ЦБР та його професійна діяльність «є неконституційними» [6].

Так, у Постанові суду зазначено: «Ми скасовуємо та ліквідовуємо спростовану нами Постанову Міністерства внутрішніх справ від 01.04.1963 року, згідно з якою було засновано ЦБР. Ми стверджуємо, що ЦБР не $є$ ані органом, ані частиною Поліцейських сил спеціального призначення Делі, тому воно не може розглядатися як поліцейський орган, 
який було створено відповідно до Закону «Про Поліцейські сили спеціального призначення Делі». Ця постанова МВС не була ні рішенням всього Уряду, ні наказом до дії з боку Президента. Дії ЦБР із реєстрації кримінальних справ, арешту правопорушників, здійснення пошуку та захоплення, доведення до суду справи правопорушника тощо порушують ст. 21 Конституції, тому мають бути заборонені як антиконституційні» [6]. Навіть сьогодні в Індії не прийнято необхідного окремого законодавства про професійну діяльність ЦБР. Протягом минулих 6 років (2013-2019рр.) Верховний суд Індії так і не розглянув Постанови Вищого суду міста Гувахаті, залишивши ії на сьогодні чинною [7].

Нині ЦБР є правоохоронним підрозділом не МВС, а Міністерства кадрів, державних скарг та пенсій Республіки Індії. Керівництво цим міністерством здійснюється сумісно Прем'єр-міністром держави (на сьогодні - Нарендра Моді) та профільним міністром (зараз Джинтендра Сінгх) [9].

Саме ж ЦБР безпосередньо очолює Директор, яким на сьогодні є Шрі Ріші Кумар Шукла [5].

За даними офіційного інтернет-сайту ЦБР, функціональними підрозділами його центрального апарату є:

«1) У Управління у боротьбі з корупцією - $є$ відповідальним за збір інформації про корупційні діяння, збір скарг на корупційні діяння державних службовців; розслідує кримінальні справи проти державних службовців;

2) Управління у боротьбі з особливими кримінальними злочинами - займається всіма справами щодо економічних злочинів та справами про внутрішню безпеку, шпіонаж, саботаж, розповсюдження наркотичних та психотропних речовин, незаконний обіг стародавніх предметів, вбивства, бандитизм / розбійні напади, шахрайство, порушення юридичних обов'язків, підробку грошових знаків, смерті жінок через придане, підозрілі смерті, міжнародний рекет, масштабне шахрайство, яке зачіпає власність або доходи Уряду, злочини загальнонаціонального значення;

3) Управління у боротьбі з економічними злочинами - розслідує фінансові злочини, банківські афери, відмивання коштів, незаконні операції на фінансовому ринку, хабарі в секторі державних установ та банків;

4) Управління технічних консультацій - надає експертне керівництво та допомогу службовцям ЦБР у розслідуванні злочинів у банківській, податковій, технічній, зовнішньоекономічній сферах;

5) Управління із судового переслідування - надає юридичні консультації у справах, які розслідуються ЦБР; тлумачить індійське законодавство та призначення спеціальних радників; пояснює статутні документи та поправки до них; готує офіційні документи для публікації у засобах масової інформації ЦБР;

6) Управління 3 питань політики ЦБР - займається питаннями політики ЦБР, процедурними та організаційними питаннями, проблемами пильності та внутрішньої безпеки в межах самого ЦБР, кореспонденції ЦБР та його зв'язків із міністерствами; опікується імплементацією Спеціальної програми щодо забезпечення пильності та антикорупції;

7) Управління 3 адміністративних питань - опікується проблемами підбору персоналу та його матеріального забезпечення;

8) Управління системного забезпечення - забезпечує потреби службовців ЦБР щодо інформаційної підтримки; відповідає на парламентські запити; надає допоміжну інформацію під час кадрових призначень та нагороджень співробітників; забезпечує комп’ютеризацію ЦБР;

9) Управління з питань координації - бере участь у формуванні Генерального поліцейського директорату, Департаменту кримінальних розслідувань; публікує інформаційний бюлетень ЦБР; підтримує всі необхідні зв'язки та співробітництво між ЦБР та Інтерполом; 
10) Ц Центральна лабораторія судово-медичної експертизи - надає експертні судовомедичні висновки в межах розслідувань кримінальних справ;

11) Академія ЦБР у м. Газіабад - здійснює професійну підготовку та перепідготовку службовців ЦБР, яка б відповідала найвищим сучасним вимогам щодо розслідування кримінальних злочинів» [5].

Указані управління, у свою чергу, є залученими для розслідування таких типів кримінальних справ (подається в авторському перекладі з мови-оригіналу джерела. - Прим. aвm.): «1) справ, які спрямовані проти службовців Центрального Уряду або законних дій Центрального Уряду; 2) справ, пов'язаних із фінансовими інтересами Центрального Уряду; 3) справ щодо порушення федерального законодавства, застосування якого, у свою чергу, має пряме відношення до Уряду Індії; 4) значних кримінальних справ щодо шахрайства, обману, розтрати фінансових коштів, інших схожих злочинів, до скоєння яких причетні компанії, що мають великі фінансові фонди, а також інших подібних справ, коли мова йде про діяння, вчинені організованими злочинними угрупованнями або професійними злочинцями, які мають свої опорні пункти у кількох штатах; 5) справ, які мають міжтериторіальне та міжнародне значення та до яких причетні кілька офіційних відомств, якщо $є$ необхідність у тому, щоб лише один правоохоронний орган здійснював необхідне розслідування» [5].

Висновки. На сьогодні ЦБР Республіки Індія $є$ певним функціонально-цільовим аналогом американського ФБР, не охоплюючи, на відміну від нього, проблематики загроз національній безпеці країни. Так, воно не здійснює розвідувальної та контррозвідувальної діяльності за зразком ФБР, яку, у свою чергу, виконує НАР.

Компетенційною прерогативою ЦБР $€$ розслідування цілої низки тяжких кримінальних злочинів у межах усієї Індії, хоча, на відміну від ФБР, його професійні права в індійських штатах суттєво обмежені.

Певним пріоритетом у професійній діяльності ЦБР $є$ розслідування кримінальних злочинів, скоєних урядовими службовцями. Насамперед ідеться про корупційні діяння. Нині великою проблемою для індійського ЦБР залишається відсутність окремого чіткого законодавства про його професійну діяльність.

\section{Список використаних джерел}

1. ССБ РФ : вебсайт. URL: http://www.fsb.ru/ (дата звернення: 09.06.2020).

2. Ходатенко Е.Н. К вопросу о создании Национального Агентства Расследований Индии: историко-правовой аспект. Вестник Московского университета МВД России. 2009. № 9.

3. Australian Security Intelligence Organization. URL: https://www.asio.gov.au/what-we-do.html/ (дата звернення: 13.05.2020).

4. Canadian Security Intelligence Service. URL: https://www.canada.ca/en/services/defence/ nationalsecurity.html (дата звернення: 21.08.2020).

5. Central Bureau of Investigation of Indian Republic. URL: http://cbi.gov.in/history.php (дата звернення: 15.08.2020).

6. Gauhati High Court rules CBI is «unconstitutional». URL: https://www.indiatoday.in/ india/story/cbiunconctitutional-illegal-guwahati-high-court-216776-2013-11-07 (дата звернення: 21.08.2020).

7. Guest Post: The Unconstitutionality of the CBI. URL: https://indconlawphil.wordpress.com/ 2018/12/24/guest-post-the-unconstitutionality-of-the-cbi/ (дата звернення: 21.08.2020).

8. Home Ministry of Indian Republic, Resolution, 1.4.1963. URL: http://cvc.gov.in/sites/ default/files/vm17ch1/GoI\%20Resolution\%20No.\%204-31-61-T,\%20dated\%201-4-1963.pdf/ (дата звернення: 13.08.2020).

9. Ministry of Personnel, Public Grievances and Pensions of Indian Republic. URL: http://persmin.nic.in (дата звернення: 14.09.2020). 27.09.2020).

10. National Investigation Agency. URL: https://www.nia.gov.in/about-us.htm (дата звернення:

11. National Investigation Agency Act, 2008. URL: https://mha.gov.in/sites/default/files/ The\%20National\%20Investigation\%20Agency\%20Act\%2C\%202008_1.pdf (дата звернення: 25.09.2020). 
12. Security Service MI 5. URL: https://www.mi5.gov.uk/what-we-do (дата звернення: 18.08.2020).

13. State Security Agency. URL: https://www.gov.za/state-security-agency-0 (дата звернення: 03.09.2020).

14. The Delhi Special Police Establishment Act, 1946. URL: http:/home.wb.gov.in/content/ 1433144840The Delhi_Special_Police Establishment_Act_1946.pdf (дата звернення: 19.08.2020).

15. USA Code. URL: ${ }^{-}$https:///www.law.cornell.edu/uscode/text/28/part-II/chapter-33 (дата звернення: 23.09.2020).

\title{
References
}

1. FSB RF : vebsajt [FSB RF : website]. URL: http://www.fsb.ru/ (data zvernennia: 09.06.2020) [in Russian].

2. Hodatenko, E. N. (2009). K voprosu o sozdanii Nacional'nogo Agentstva Rassledovanij Indii: istoriko-pravovoj aspekt [On the question of the creation of the National Investigation Agency of India: historical and legal aspect]. Vestnik Moskovskogo universiteta MVD Rossii. № 9 [in Russian].

3. Australian Security Intelligence Organization. URL: https://www.asio.gov.au/what-we-do.html/ (data zvernennia:13.05.2020).
4. Canadian
Security
Intelligence
Service.
URL: https://www.canada.ca/en/services/defence/nationalsecurity.html (data zvernennia: 21.08.2020).

5. Central Bureau of Investigation of Indian Republic. URL: http://cbi.gov.in/history.php (data zvernennia: 15.08.2020).

6. Gauhati High Court rules CBI is «unconstitutional». URL: https://www.indiatoday.in/india/story/cbiunconctitutional-illegal-guwahati-high-court-216776-2013-11-07 (data zvernennia: 21.08.2020).

7. Guest Post: The Unconstitutionality of the CBI. URL: https://indconlawphil.wordpress.com/2018/12/24/guest-post-the-unconstitutionality-of-the-cbi/ (data zvernennia: 21.08.2020).

8. Home Ministry of Indian Republic, Resolution, 1.4.1963. URL: http://cvc.gov.in/sites/default/files/vm1 7ch1/Gol\%20Resolution\%20No.\%204-31-61-T,\%20dated\%201-41963.pdf/ (data zvernennia: 13.08.2020).

9. Ministry of Personnel, Public Grievances and Pensions of Indian Republic. URL: http://persmin.nic.in (data zvernennia: 14.09.2020).

10. National Investigation Agency. URL: https://www.nia.gov.in/about-us.htm (data zvernennia: 27.09.2020).

11. National Investigation Agency Act, $2008 . \quad$ URL: https://mha.gov.in/sites/default/files/The\%20National\%20Investigation\%20Agency\%20Act\%2C\%202008_1.pdf (data zvernennia: 25.09.2020).

12. Security Service MI 5. URL: https://www.mi5.gov.uk/what-we-do (data zvernennia: 18.08.2020).

13. State Security Agency. URL: https://www.gov.za/state-security-agency-0 (data zvernennia: 03.09.2020).

14. The Delhi Special Police Establishment Act, 1946. URL: http://home.wb.gov.in/content/1433144840The_Delhi_Special_Police_Establishment_Act_1946.pdf (data zvernennia: 19.08.2020).

15. USA Code. URL: https://www.law.cornell.edu/uscode/text/28/part-II/chapter-33 (data zvernennia: 23.09.2020).

\author{
Epryntsev Pylyp, \\ $\mathrm{PhD}$ in Law \\ (Donetsk Law Institute, MIA of Ukraine, Kryvyi Rih) \\ ORCID: https://orcid.org/0000-0002-9790-9565
}

Nosevych Nadiya

(Donetsk Law Institute, MIA of Ukraine, Kryvyi Rih)

ORCID: https://orcid.org/0000-0002-1112-9788

INDIA CENTRAL INVESTIGATION BUREAU:

\section{HISTORY, LEGAL BASIS OF PROFESSIONAL ACTIVITY, TASKS, STRUCTURE}

The law enforcement component provides for actions to ensure the rights and freedoms of citizens and protect the national interests of the state. It maybe done through the fight against organized crime, including international terrorism, the investigation of certain illegal acts, the restoration of an effective system of national security and defense. In the framework of this scientific and legal article, the author considered the history, legal basis of professional activity, structure and tasks of the Central Bureau of Investigation of India. Today's Indian CBI is a certain functional-targeted analogue of the American FBI, but does not cover, 
in contrast, the issue of threats to India's national security. Considering these subject aspects, the scientist turned to the current legislation of India on the professional activities of the CBI, the official website, as well as the scientific works of some domestic and foreign experts on this issue. An analysis of these and other sources revealed that the Central Bureau of Investigation of India today is a functional target of the US FBI, whose prerogative is to investigate a number of serious crimes throughout India, although, unlike the FBI, its professional rights in India states are significantly limited. The Bureau of Investigation does not carry out intelligence or counterintelligence activities, following the example of the FBI. The priority in the professional activities of the Central Bureau of Investigation of India is the investigation of criminal offenses, primarily corruption. Incomplete regulatory regulation of its activity remains a big problem for this body. The CBI's prerogative is to investigate a number of serious crimes throughout India, although, unlike the FBI, its professional rights in the Indian states are severely limited. A certain priority in the CBI's professional activities is the investigation of criminal offenses committed by government officials. First of all, we are talking about acts of corruption. A major problem for today's Indian CBI is the lack of separate clear legislation on its professional activities.

Key words: CBI; investigation; CBI structure; CBI unit; CBI officer.

Надійшла до редколегії 17.11.2020 